IRA-International Journal of Management \& Social Sciences

ISSN 2455-2267; Vol.05, Issue 01 (2016)

Pg. no. 87-97

Institute of Research Advances

http://research-advances.org/index.php/RAJMSS

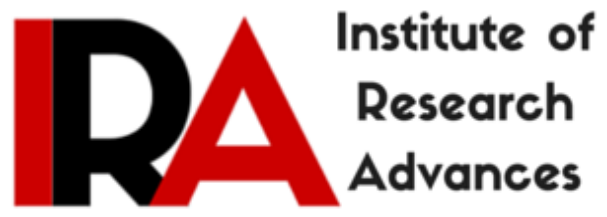

\title{
Prospect of Tourism Development on the Mambilla Plateau: Lessons From Obudu Mountain Resort, Nigeria
}

\author{
${ }^{1}$ Oruonye, E.D., ${ }^{2}$ Ahmed, Y.M. and ${ }^{3}$ Tukura Ejati D.H. \\ $1,2,3$ Department of Geography, Taraba State University, \\ P.M.B. 1167, Jalingo, Taraba State, Nigeria.
}

Type of Review: Peer Reviewed.

DOI: http://dx.doi.org/10.21013/jmss.v5.n1.p10

\section{How to cite this paper:}

E.D., Oruonye, Y.M., Ahmed, \& T.H., Ejati Tukura (2016). Prospect of Tourism Development on the Mambilla Plateau: Lessons From Obudu Mountain Resort, Nigeria. IRA-International Journal of Management \& Social Sciences (ISSN 2455-2267), 5(1), 87-97. doi:http://dx.doi.org/10.21013/jmss.v5.n1.p10

(C) Institute of Research Advances

(cc) EY-NC

This work is licensed under a Creative Commons Attribution-Non Commercial 4.0 International License subject to proper citation to the publication source of the work.

Disclaimer: The scholarly papers as reviewed and published by the Institute of Research Advances (IRA) are the views and opinions of their respective authors and are not the views or opinions of the IRA. The IRA disclaims of any harm or loss caused due to the published content to any party. 


\section{ABSTRACT}

Tourism provides one of the most important avenues to achieve economic diversification in Taraba State and Nigeria in particular in the face of the present economic challenges all over the world. This study examines the prospect of tourism development on the Mambilla plateau of Taraba State Nigeria and the lessons that can be drawn from the Obudu Mountain Resort. The data used in this study was generated from existing sources of data, journal articles, relevant textbooks, online materials, field trips and interviews with government officials and individuals from the study area. The findings of the study shows that despite the rich tourism potentials of the area, traffic flow has been very low owing to a number of challenges. Some of these challenges include inaccessibility of most of the important tourist sites, poor transportation network and connectivity, lack of awareness and poor infrastructural development. The findings of the study also shows striking similarity in the physical environment of Obudu mountain and Mambilla plateau and some of the advantages of the Mambilla plateau over Obudu mountain. Based on the findings of this study, there is need for the government to be more proactive towards tourism development in the area. The state can do well by completing the design of the state tourism development master plan that started many years back. This will provide the required roadmap to tourism development in the state.

Keywords: Development, Mambilla, Obudu, Prospect, Resort and Tourism

\section{Introduction}

Tourism provides one of the most important avenues to achieve economic diversification in Taraba State and Nigeria in particular in the face of the present economic challenges all over the world. Tourism involves activities of persons travelling to and staying in places outside their usual environment for leisure, business and other purposes. Getis et al (2004) defined tourism as undertaking for the purpose of recreation rather than business. Tourism has become not only the most important single tertiary sector activity but is, as well, the world's largest industry in jobs and total value generation. Tourism, from socio-economic and political point of view have been globally acknowledge and accepted as a relatively new innovation in the human history of planned development (Dawaki, 2005). Today, tourism has been recognised the world over as a special economic endeavour that showers the global society with better chances of understanding one another; a tool for enhancing economic values as avenue through which the menace of unemployment and incessant rural urban migration could be addressed. The economic benefits of tourism are many and varied. Some of these include tourism sales, profits, tax revenue, jobs and income in an area. The most direct benefits are within the primary tourism sector, lodging, restaurants, transportation, amusements and retail sales (Orga and Adah, 2010). The main sources of revenue in tourism enterprise have been outlined by Obot (2008) to include the following;

i. User fees charged to individuals on entry into a resort or important tourist destination.

ii. Concession charged to individuals or groups licensed to provide service to visitors (such as food, lodging, transportation, guide services and retail stores).

iii. Sales and Royalties which are a percentage of earnings from activities or products of a tourist visit.

iv. Taxation of goods and services used by tourist (including hotel, food and airport taxes).

v. Donations solicited from tourist for special projects in tourist destinations.

Tourism provides for cultural pride, greater awareness of natural environmental endowment and its economic values, a sense of ownership and reduction in vulnerability of the poor through income diversification (Orga and Adah, 2010). 
Thus, today tourism is seen as a goldmine which any nation, state or community endowed with it cannot afford to neglect. Every summer, affluent Nigerians and Taraba state indigenes travel out of the country to visit tourist destinations in Europe and America without thought about important tourist destinations within the state and country. Every year also the world tourism day is celebrated on the Mambilla plateau on $28^{\text {th }}$ September. The people in the area used the occasion to showcase some of the rich cultural heritage and eco-tourism potential of the plateau. Government officials in the state and politicians are invited and long speeches and promises are made. After this, no concerted effort is made to harness these potentials and translate it into productive venture. Tourism development goes beyond mere annual ceremonies. Tourism development requires huge investment in order to properly harness the rich benefits inherent in it. This makes it very imperative for the Taraba State government to take a bold step towards the possible tapping of the potentials embodied in this great goldmine.

The Mambilla Plateau has a distinct amiable climate with its temperate element making it a prime location for many people. The Mambilla plateau has variously been described as the little Europe in Nigeria. It is no wonder that many Nigerian past leaders and high profile individuals in the country have acquired properties on the plateau. The plateau is a resource frontier zone replete with abundant natural resources such as agricultural crops, mineral resources, wildlife, beautiful scenery and lots more that far outweigh the Obudu plateau. Unlike the Obudu plateau, the Mambilla plateau has far more land area and many towns that have developed for centuries. The wide range diversity of natural resources that are yet to be harnessed on the Mambilla plateau made Oruonye and Abbas (2011) to conclude that if Taraba State is nature's gift to the nation of Nigeria, then Mambilla plateau is nature's gift to Taraba State. Mambilla plateau is located on a more higher altitude than Obudu plateau. The highest point in Nigeria, Chappal Wadi with height of 2,419m.a.sl. is found on the Mambilla plateau. It is often called the mountain of death because of the height and steep nature of the slope. The plateau houses the Ngel Nyaki mountain forest reserve managed by scientist from New Zealand.

Thus, Mambilla plateau has far more natural and cultural tourist attraction that could be developed into tourist resort to make the state a world class choice tourist destination for local and international visitors. This study attempt to project some of this important tourist resources and destination that can fully be harness into tourism development and how this can benefit the local communities and Taraba state as a whole. The study attempt to draw lessons from the Obudu Mountain Resort to show what the Cross River state Government did that Taraba State Government need to do if it decide to develop tourism in the state into a world class standard and a choice destination of tourist in Nigeria.

\section{Materials and Methods}

\section{Description of Study Area}

The Mambilla plateau is located between latitude $5^{\circ} 30^{\prime}$ to $7^{\circ} 18^{\prime} \mathrm{N}$ and longitude $10^{\circ} 18^{\prime}$ to $11^{\circ} 37^{\prime} \mathrm{E}$ with a total land mass of $3,765.2 \mathrm{~km}^{2}$ forming the southernmost tip of the north eastern part of Nigeria (Tukur et al, 2005) (Fig. 1). The entire area of the plateau fall under the Sardauna local government area in Taraba State Nigeria. The plateau is 'Cameroon-locked' in its southern, eastern and almost half of its western part (Tukur et al, 2005). The plateau is the highest elevation in West Africa (Frantz, 1981). Agriculture forms the economic mainstay of the people with estimated total land areas of about $83.6 \%$ and $8.3 \%$ devoted to range land and crop cultivation (Tukur and Zemba, 2005). The area is inhabited by the Mambilla people and Fulani cattle rearer along side with other smaller ethnic groups like Panso, Kambu and Kaka. The Mambilla people and the other ethnic groups are mainly crop farmers. Mambilla plateau is a land of beauty and wonders, replete with vast arable lands suitable for a wide range of agricultural crops such as maize, guinea corn, banana, plantain, beans (not cowpea), cassava, Irish potato, yam, cocoyam and cash crops such as tea, coffee, kolanut (accumulata), cocoa, avocado pear, soya beans, groundnut, apple and wheat. There exist coffee, tea, cocoa and palm oil plantations on Mambilla plateau. 
There is a cocoa research institute at Kusuku on the plateau. The forest of the Mambilla plateau provides lumberable trees that are felled for timber production and taken to different parts of the state and country for sale. Hence, lumbering is an important economic activity undertaken by the local people. The lumberable trees are sawn into different timber products. The Mambilla plateau also provides a good grazing ground for livestock. The plateau is free from tsetse fly infestation which characterizes the plains. It has been observed that over six million heads of cattle exist on the Mambilla plateau in the 1980s (Frantz, 1981). Grazing is the major land use on the plateau which has resulted in frequent clashes with crop farmers. There exist different springs and waterfalls on the Mambilla plateau, which include the Njeke falls, the Chama and Mbujum falls and the Tiyi falls at Dorofi. The rain-bearing winds on the Mambilla plateau are from the south-west. The rainy season lasts for an average of 250 days, from March to October (Iyamabo et al, 1972). Mean annual rainfall exceeds $1780 \mathrm{~mm}$ with peaks in June/July and September (Chapman and Chapman, 2001). The start of the rains is often marked by furious squalls. The dry season lasts for about three months. The rains begin to slacken off early in November, and the dry season has usually begun by the second week in that month. Between December and February rainfall is normally minimal, at Gembu for example, the average for these three months was $80 \mathrm{~mm}$. In the driest year, December and January were without any rain (Chapman and Chapman, 2001).

The Mambilla plateau is one of the places in Nigeria that is well endowed with abundant natural resources. The plateau is endowed with a semi temperate climate that is suitable for agricultural crop production and livestock rearing, as well as mineral resources. The Mambilla plateau has the second largest tea plantation in the world, second to the one in India. Despite the natural endowment of the Mambilla plateau, the livelihood of the rural dwellers in the area has been greatly constrained by increasing population pressure on natural resource, shortage of farmlands and increasing conflicts between the Fulani herdsmen and the local Mambilla crop farmers. Mining of gemstones have over the years provided an alternative source of income to most rural dwellers on the Mambilla plateau. This is especially during the off farm season. Tourist flow on the Mambilla plateau are usually high in the months of May and June which is adjudged to be the best visiting periods because it is the midway between the excessive dry and wet seasons on the plateau (Galtima, 2005).

\section{Sources of Data}

The study relied substantially on existing sources of data, journal articles, relevant textbooks and online materials. Field trips and interviews with government officials and individuals from the study area who have good knowledge of the Mambilla plateau and environ were conducted. The interviews were carried out to confirm or explain information from the literature reviewed and give clues where information are lacking in the literatures reviewed. The data generated were analysed using descriptive statistics. 


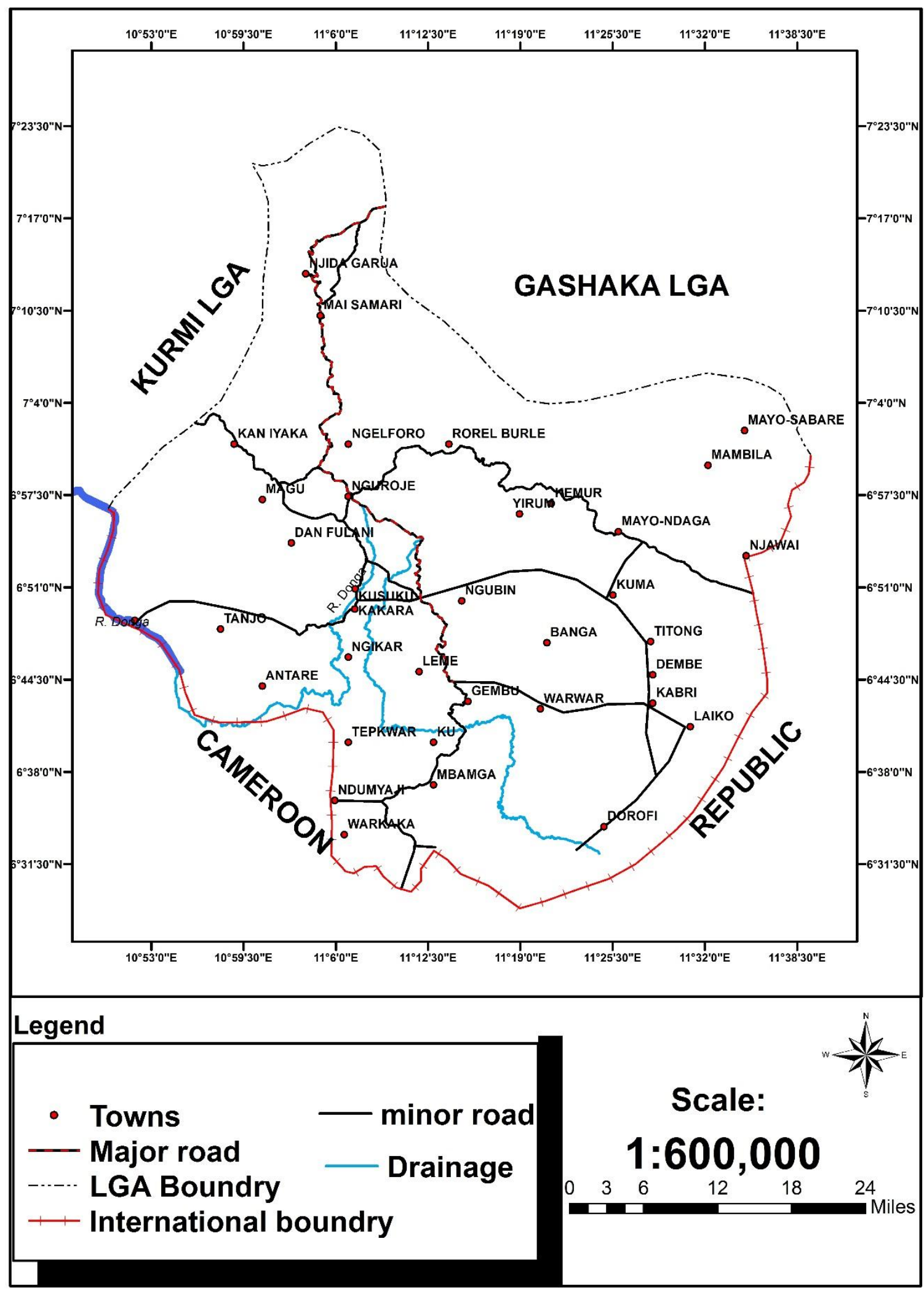

MAP OF SARDAUNA LGA 


\section{Result of Findings}

Taraba state is endowed with huge and diverse tourism resources which need to be harness and efficiently developed to improve the living condition of the people. These tourism resources include the numerous rivers cascading the Mambilla plateau, the waterfalls, the lush grassland vegetation, the unique flora and fauna of the forest reserve and Gashaka Gumti National Park, the scenic mountain slope and valleys. Others include the rich cultural artefacts, traditional festivities, music and dances of the people in the area. What is required is the development of the tourist resources and facilities. Development of tourist facilities involves large scale construction of infrastructures. This will lead to increase resource demand and influx of foreign people in the area. It will entail that measures must be taken to address all the needs and concerns of local communities to ensure equitable sharing of benefits from tourism. The tourist potentials of the Mambilla plateau have been highlighted by Galtima (2005). This includes ecotourism and cultural tourism.

\section{Eco -tourism Potentials of Mambilla Plateau}

Galtima (2005) observed that the Mambilla plateau present opportunity for ecotourism development in many ways, one of which is the semi-temperate climatic background of the plateau. Others include the beautiful scenery of the country side, which is characterized by rolling or 'basket of egg' topography, the numerous perennial streams and montane vegetation dotted by pockets of forest reserves among others.

The scenic Donga River valley provide opportunity for hydroelectric power development in the area. The several streams flowing down the plateau have resulted in the formation of many waterfalls which include the following;

i. The Wajuru waterfall in Titon ward, Sardauna LGA.

ii. The Barup waterfall (proposed site for the multi-billion naira HEP development project).

iii. The Sukel waterfall.

iv. Tiyi waterfall at Dorofi

v. The Njeke waterfall

vi. The Chama and Mbujum waterfall

vii. The Tunga Dam/Lake.

a. The Ngel Nyaki National Game Reserve (Southern part of Sardauna LGA).

b. Titong Forest.

c. The proximity of the Mambilla Plateau to the Gashaka-Gumti Game reserve located at the foot of the Plateau offers a double advantage for the Mambilla tourist centre.

At the foot of the Mambilla plateau lies the Gashaka-Gumti National Park (GGNP). The Park is a vast land of spectacular wilderness $\left(6,000 \mathrm{~km}^{2}\right)$ in the southeast corner of Taraba State, adjoining the Mambilla Plateau. Mostly mountainous, from 457 to 2407 meters, it contains Nigeria's highest mountain, Chapal Waddi $(2409 \mathrm{~m})$. It is the most ecologically diverse conservation area in the country and contains swaths of guinea savannah, gallery forest, moist forest, mountain forest and grassland. It is the most diverse in terms of species in the whole of West Africa, harboring such rare animals like the colobus monkey and warthogs, including buffalo, roam antelope, chimpanzee, hippopotamus, hyena, giant forest hog, lion and leopard. It is home to some highly endangered species of wildlife such as cheetah, red river-hog, mountain reedbuck, sitatunga, African civets, yellow-backed duikers, piping hornbill, green turaco, pangolins etc. The recreational facilities and hotel accommodation in the Park will require upgrading to attract international visitors and very important personality. 


\section{Cultural Tourism Potential}

The Mambilla plateau is well endowed with rich cultural heritage. This includes the cultural festivals, dances and music of the various ethnic groups in the area. Some of the festivities are used to mark the beginning of farming season, harvest season, religious festivities such sallah celebration and Christmas celebration. The traditional songs and dances are used to commemorate specific events in the life of the people. Some of them include;

\section{a. Kaka ethnic group}

i. Soh dance - strictly for youth and men 15years and above held between March and April every year during the hunting festival.

ii. Medik dance - dance by women consisting of sweet melody carried out in the night three days before the hunting festival begins. It is believed that the sweet song and melody of Medik dance attracts more animal into the forest.

iii. Cham dance - this is a mass victory dance particularly after war.

iv. Iajok dance - this is a marriage dance.

v. Meback dance - this is a harvest festival dance.

vi. Chimbir - this is a harvest festival dance.

vii. Garuh Dance - this is a wedding ceremony dance

viii.Ngee Fack Dance - this is a farming season dance

ix. Rom Dance - this is a funeral dance perform when an elderly person dies.

\section{b. Mambilla ethnic group}

i. Trim dance - harvest festival dance (Mbamga)

ii. Kati dance - Elderly marriage dance (Kabri)

iii. Bohl dance - dance among Leme people

c. Panso ethnic group - Masquerades dance

\section{d. Kanbu ethnic group -}

Other cultural tourism potentials in the area include historical sites such as
a. Mbamnga Cave
b. Ndumyaji Cave
c. Historic site of ancient blacksmiths
d. The location of the Nigerian Foot Ball Association (NFA) high altitude training camp on the plateau is a potential booster for tourism in the state.

e. There is an old airstrip at Serti (approximately $1.1 \mathrm{~km}$ long and $15 \mathrm{~m}$ width) which was constructed by the Christian Reform Church of Nigeria (CRCN) but was taken over by the Federal Government in 1999. Light aircrafts use the old airstrips to provide air charter services whenever necessary. This can be rehabilitated and upgraded to boost tourism in the area. 
f. Although Taraba State Government has a guesthouse on the plateau which caters for government visitors and VIP guests, it is not open to commercial use. The local government council owns the Baju guesthouse. There is need for modern commercial hotels that will cater for tourism activities in the area.

\section{Lessons from Obudu Mountain Resort}

Looking at the similarities between physical environment in Obudu plateau and Mambilla plateau, it is important to examine some of the deliberate effort that was made to develop tourism on the Obudu plateau that can serve as lessons for developing tourism on the Mambilla plateau. They include;

\section{i. Infrastructural Development}

There was deliberate effort by the former governor of Cross River State to invest massively on infrastructural development of the Obudu mountain resort. Thus, the former Governor of the State, Mr. Donald Duke invested heavily in developing the following infrastructures;

i. Construction of road networks from the foot $\mathrm{f}$ the mountain to the hilltop and connecting important locations within the resort.

ii. Administrative office to take care of the day to day running of the resort.

iii. A modern accommodation guest house for various classes of visitors to the resort starting from standard double chalets, superior double chalets, Executive suites, Royal suites, Governors lodge, Presidential suite, Mountain villas, African bungalows, Presidential retreat villa and Safari lodges.

iv. Ultra modern Gymnasium centre.

v. Tennis and squash courts.

vi. 9 hole golf course.

vii. Water Parks with adult and children swimming pools of Olympic standard.

viii. Natural swimming pool.

ix. An international conference centre with conference hall seating 250 persons with 2 breakaway rooms seating up to 40 persons.

x. An international Restaurant for local and international delicacies.

xi. A clinic with qualified doctors and nurses. The resort clinics serve as quick medical intervention and treatment of minor illnesses resulting from either change of weather or altitude.

xii. A police security outpost station to enforce maximum security in the area.

xiii. An international cable car for easy transportation from the foot of the mountain to the hilltop of $11 \mathrm{~km}$. This offers tourist to the resort bird's eye view of wonders of nature in the area.

xiv. An airstrip at the foot of the Obudu plateau that maintains flight operation from Calabar and Abuja to the resort.

xv. Constant electricity and potable water supply.

xvi. The government built modern market in the form of lockup shops to facilitate commercial interaction between local community members and tourist to the resort. The market act as cheaper outlet for tourist needs on the resort.

Even without large scale infrastructures, the local people can be mobilized to provide accommodation and act as guides to group of tourist that are adventurous and seek to enjoy wilderness experience in the area. Adventurous tourist will find open air camping and hiking through the mountain paths both challenging and rewarding (Obot, 2008).

\section{ii. Harnessing of Natural Environment}

The natural beautiful scenery of the Obudu plateau has been properly harnessed by developing it into important tourist attraction site on the mountain resort. This includes;

a. The Grotto walk way and waterfall.

b. Cattle rack and horse riding 
c. Monkey face views

d. Ilumo festivals with local dishes and brew.

e. Holy mountain site

f. Becheve nature reserve viewing of rarest bird species. The reserve offers opportunities for bird viewing through the canopy walkway.

g. Hiking trails through some of the spectacular ranges.

h. Quatermala trail

It is hoped that Taraba State government can borrow a leaf from the experience of the Obudu mountain resort and develop a tourist resort on the Mambilla plateau. This will go a long way in transforming the region into a world class tourist destination centre in Nigeria, improving infrastructure of the area, provide employment opportunity to the teaming youth population in the area and achieving the economic diversification drive of the state government. The state government investment in tourism usually attracts supportive investment by Federal Government and International NGOs as was the case at Obudu mountain resort.

Despite their potentials as important tourist sites for leisure activities, accessibility remains a great challenge to their development. Also, despite the huge potentials of tourism on the Mambilla plateau, tourist flow in the area has been very low. Galtima (2005) observed that the average number of visits recorded from hospitality outfits in the area such as the Tea estate and Tunga dam hotel/guesthouse account for only 100 tourist per month. This does not include tourist who stayed with friends and relatives. The low flow of traffic tourist on the Mambilla plateau has been identified by Galtima (2005) as follows;

i. Lack of awareness of the tourism potentials of the Mambilla plateau both nationally and internationally. The Mambilla plateau is not popularly known as a tourist destination outside the north eastern region of the country. Tourism development requires a lot of publicity by way of advertisement. This is an important avenue to provide information to tourists within the state, country and around the world to visit such place. Countries like Malaysia has invested in this direction both on local and international television channels such as CNN, BBC in order to give vital information on their rich culture and endowed environments for tourists around the world, especially with their beautiful song that ends with "Malaysia truly Asia" (Terwase et al, 2015). Lepp, Gibson and Lane (2014) observed that Uganda did same efforts in providing information for tourists around the world through their official website where people can actually access free information on such destinations in their country. Such efforts are carried out for the purpose of enhancing travel motivations for tourists who have little knowledge on such destinations. (Terwase et al, 2015). This also helps in removing fears of the unknown which the tourists may face in decision making before embarking on such travel.

ii. Inaccessibility of most of the important tourist site and difficulty of transportation in the area. There are serious difficulties in transportation to the towns on the plateau. This is made worse by the rugged topography and erosion in the area. Most of the communities can be accessed through motorbike only.

iii. Conflicts - Tourism cannot develop in area that suffers from ethno-religious or communal conflict. Peace is a sine qua non for meaningful and sustainable tourism development in an area. The conflict on the Mambilla plateau are usually over resources such as farming and grazing land, poverty and youth restiveness as a result of unemployment. These are the problems that the government can deal with and the development of tourism can help overcome by providing employment opportunities and desired infrastructure that will stimulate industrial activity and economic growth in the area. 
iv. Border location - The Mambilla plateau is located at the border with Republic of Cameroon just like Obudu plateau. This result in cross border flows of human traffic, with potential for cross border movement of arms and ammunition.

\section{Conclusion}

This study have added to our understanding of the prospect of tourism development on the Mambilla plateau of Taraba State Nigeria and the lessons that can be drawn from the Obudu Mountain Resort. The findings of the study shows striking similarity in the physical environment of Obudu mountain and Mambilla plateau and some of the advantages of the Mambilla plateau over Obudu mountain. The findings of the study shows that despite the rich tourism potentials of the Mambilla plateau, tourist flow to the area has been very low owing to a number of challenges. Some of these challenges include inaccessibility of most of the important tourist sites, poor transportation network and connectivity, lack of awareness and poor infrastructural development. The main weakness of this study is the paucity of data on tourist flow in the area and literature on some of the cultural heritage of the people in the area. Based on the experience of Obudu Mountain Resort, there is need for the Taraba State government to be more proactive in tourism development in the area. The state can do well by completing the design of the state tourism development master plan that started many years back. This will provide the required roadmap to tourism development in the state. This study recommends the need to explore further the cultural tourist resources of the Mambilla plateau.

\section{Reference}

1. Chapman, J.D. and Chapman, H.M. (2001). The forest flora of Taraba and Adamawa States, Nigeria: An ecological account and plant species checklist. University of Canterbury, New Zealand.

2. Dawaki, A.M. (2005). "Memorandum on the need for Federal Government Assistance towards the enhancement of the states of Tourism Industry'. Paper presented at the 3rd National Council meeting for Cultural Tourism held in Umuahia - Abia State 22nd - 23rd June, 2005.

3. Frantz C. Development without communities: Social fields, networks and action in the Mambilla grasslands of Nigeria. Human Organization. 1981;40:211-220.

4. Getis, A., Judith, A. and Jerome, D.F. (2004). Introduction to Geography. $9^{\text {th }}$ edition. New York, McGraw Hill Higher Education pp.416-466.

5. Iyamabo DE, Jackson JK, Ojo GOA. Pine trials in the Savanna areas of Nigeria. Research paper (Savannah series) No. 11. Federal Department of Forest Research, Ibadan; 1972.

6. Lepp, A., Gibson, H., and Lane, C. (2014) The Effect of Uganda's Official Tourism Website on Travel Motivations and Constraints, Journal of Travel \& Tourism Marketing, 31:6, 712-730, DOI: $10.1080 / 10548408.2014 .884967$

7. Obot, E. (2008). Linking Tourism Profitability to Environmental Responsibility: The Okwangwo Experience and the Gashaka-Gumti Potential. In Aremu D.A. (Ed.) Preservation of Land, Culture and Wildlife for the Development of Ecotourism in Africa. Spectrum Books Limited, Ibadan Nigeria. Pp. 56-60.

8. Orga, D.Y. and Adah, G. (2010). Inventory of Tourism Resources in Nassarawa State Nigeria. 
Journal of Research in Development. Vol. 8(1). Pp. 1-5.

9. Tukur AL, Adebayo AA and Galtima A. (Eds.). The Land and People of the Mambilla Plateau. Heinemann Educational Books (Nig.) Limited; 2005.

10. Tukur AL, Zemba AA. Agriculture. In Tukur AL, Adebayo AA, Galtima M, (Eds). The land and people of the Mambila Plateau: Heinemann Educational Books (Nig) PLC; 2005.

11. Terwase, I.T., Abdul-Talib, A.N., Edogbanya, A., Zengeni, K.T., Yerima, H.M. and Ibrahim, M.B. (2015). Obudu Cattle Ranch: A Tourist Destination in Nigeria. Research on Humanities and Social Sciences, Vol.5, No.20, pp 67-71. 